\title{
Central Bank Independence and Accountability: The New Zealand Case
}

\author{
Stephen Kirchner
}

O everal countries have recently sought to give their central banks greater independence from government. Most notably, the Reserve Bank of New Zealand Act 1989 attempts to put a central bank on a more independent footing, without loss of government control over the determination of monetary policy objectives. In the UK, the House of Commons Treasury Committee has recently recommended that the Bank of England be given a similar degree of independence to that of the Reserve Bank of New Zealand (RBNZ) (House of Commons, 1993). In Australia too, debate has occurred over whether the Reserve Bank should be placed on a more independent legislative footing.

These developments reflect concern that central banks are subject to inappropriate political incentives in their conduct of monetary policy, resulting in policies inimical to price stability and thus to broader macroeconomic performance. Central banks and their political masters also suffer from time-inconsistency problems, whereby policy action promised now may be inconsistent with what these actors perceive to be in their interests when the time comes to deliver on these promises. Time-inconsistency undermines the credibility of commitments to establish price stability in the eyes of economic actors, which in turn undermines the viability of anti-inflationary monetary policies.

These concerns appear to be borne out in a number of studies that have sought to establish a connection between greater central bank independence and improved inflation performance (Banaian et al., 1983; Bade \& Parkin, 1988; Grilli et al., 1991; Cukierman, 1992). These studies have found that although independent central banks are associated with lower rates of inflation, there is no apparent correlation between real economic performance and central bank independence (Alesina \& Summers, 1993; Cukierman et al., 1993; Grilli et al., 1991:345). However, low inflation is a desirable economic objective in itself and is widely thought to contribute to improved macroeconomic performance over the long term. Of course, low or zero inflation is not the only goal of economic policy. But monetary institutions that contribute to low inflation outcomes consistent with other policy objectives are worthy of support.

Stephen Kirchner is a graduate student in economics at Macquarie University and a Research Officer in the Australian Graduate School of Management at the University of New South Wales. 
This article examines central bank independence and its compatibility with government determination of monetary policy objectives. The new legislative framework in New Zealand is found to be less important to improved inflation performance than the government's commitment to pursuing an anti-inflationary monetary policy. The independence of the RBNZ is only as good as this commitment, suggesting that a more fundamental examination of the relationship between governments and central banks is required if anti-inflationary policies are to be sustained over the longer term.

\section{Central Bank Independence: Means and Ends}

A central bank is independent with respect to the means of monetary policy if it can choose which policy instruments to use in pursuing goals given to it by the government or by its own independent decision-making processes. The government may set objectives for the central bank, such as price stability, and then give the central bank discretion in deciding how it will go about achieving these goals. A central bank may also be independent in relation to the ends of monetary policy, in which case it decides for itself the goals that it pursues. Such ends independence may or may not include independence in respect of the means of policy. As Grilli et al. found, these two types of independence are not always positively correlated (1991:370).

It is thought that ends independence will result in the central bank opting for some form of commitment to price stability, the goal to which monetary policy is best suited. Central banks are thought to have an institutional bias in favour of low inflation, reflecting in part the long-standing association between central banks and the financial community. Central bankers are assumed to have lower rates of time preference than politicians, and different subjective trade-offs between price stability and other macroeconomic variables (Cukierman, 1992:349). Time-inconsistency problems are more pronounced when policy-makers have a high discount rate (Buckle \& Stemp, 1989:3). The significance of central bank independence depends on the existence of these different policy preferences on the part of politicians and central bankers (Goodman, 1991:329). Otherwise, there would be little point to central bank independence. Yet these assumptions may not be warranted. The empirical public-choice literature on monetary policy has demonstrated that central bankers may embody a wide range of preferences and be subject to a variety of incentives that encourage inflationary policies (see Mayer, 1990).

Most central banks enjoy considerable independence in the means they employ to achieve monetary-policy goals, subject to a variety of constraints, such as the govemment's conduct of fiscal and exchange rate policy and technical considerations. The more important issue is the independence of central banks to adopt and pursue particular policy goals without reference to the political authorities. As Banaian et al. (1983: 203) argue:

The central banks of most developed economies do not show much independence in the determination of monetary policy. Although central banks 
are almost always charged with the execution of monetary policy and some scope for disagreement with government exists, they are usually subordinate to the treasury or finance ministry in the formulation of policy.

A key question, therefore, is whether central banks should be given greater independence in determining the goals of monetary policy, in addition to the discretion they already enjoy in choosing the means of policy. Neumann provides a strong statement in favour of greater goal independence:

Trivially, there is no independence if the central bank receives and has to follow instructions issued by the government or other authorities. . . the governing body of the central bank ... should be explicitly provided with the undivided authority to decide on the target of monetary policy, on instruments and implementation procedures. (1991:100; emphasis added)

Such goal independence is thought to ameliorate the time-inconsistency problem and so provide monetary policy with greater credibility. Banaian et al. (forthcoming) show that 'distinguishing independent central banks solely on the basis of freedom from government override ... out performs the multifaceted indices [of independence] as a predictor of inflation performance for the industrial countries'. Other commentators view such goal independence as either undesirable (because monetary policy should as a matter of democratic principle be kept under political control) or unrealistic (because governments are unlikely to surrender control over an important economic policy instrument). This school of thought prefers to concentrate on means independence, accountability and policy transparency.

\section{Central Bank Accountability}

In practice, very few governments seem willing to allow their central banks substantial independence in the determination of monetary policy objectives. The prevailing public-interest doctrine of monetary policy determination holds that the government should be accountable to the electorate for its conduct of monetary policy, which means that the central bank should be subject to government direction. The President of the Federal Reserve Bank of New York has observed, 'I think we would all agree that central banks neither can nor should be fully independent of government, since it is governments - and not central banks - that hold final responsibility for the economic and financial policy of the country' (McDonough, 1994:5). The independence of central banks from government does, however, seem to have some bearing on the extent to which the latter are held accountable for economic conditions. For example, US Presidents and Congress routinely shift the blame for high interest rates on to the nominally independent Fed (see Mayer, 1990), whereas in Australia the government is more likely than the Reserve Bank to be blamed for prevailing economic conditions (Cole, 1990:2).

Even for an independent central bank, the determination of monetary policy objectives is an inherently political exercise that cannot be completely divorced 
from political considerations. Woolley describes the dilemmas facing the relatively independent US Fed as follows:

The Federal Reserve's relationships with other actors are marked by a kind of tension between its nominal political independence and the kinds of tasks it is called upon to perform in the economic system. It is asked to be politically neutral while regulating an economic system that is not neutral in its results. It is expected to act on the basis of reflective scientific judgement in an environment that stresses political responsiveness. It is asked to make technically correct decisions despite conditions of economic uncertainty that make it difficult to avoid errors and despite a highly conflictual scientific debate as to what correct policy is. (1984:12)

This view should be contrasted with that of some advocates of greater goal independence for central banks, who maintain that central banks can be largely divorced from politics by enshrining their independence at a constitutional level:

Democratic accountability is appropriate in cases where institutions make political decisions, i.e. face a trade-off with respect to competing objectives. But the independent central bank would be committed to only one objective, price stability. Hence the bank will not make political decisions but technical decisions with respect to policy implementation. (Neumann, 1991:109)

While this may be more true of a central bank whose independence is constitutional rather than statutory, it seriously understates the politically charged nature of what a central bank is called upon to accomplish. An independent central bank with a single statutory objective may still face policy trade-offs of a political nature in deciding on an appropriate path for achieving price stability and maintaining such stability in the face of economic shocks. Democratic accountability would require such trade-offs to be resolved politically.

Many advocates of greater central bank independence accept that such independence entails even greater accountability to the government, to ensure that it is used in the public interest. As the Governor of the Bank of Canada has observed, 'the greater is the responsibility assigned to the central bank, obviously the more important it is to have sound arrangements for accountability' (Crow, 1993:7). According to this conception of independence, the goals of monetary policy are still subject to political determination, but central banks enjoy greater independence to pursue those goals. The independence of central banks to pursue particular goals is enhanced through greater transparency in the conduct of policy, which reduces the scope for governments to continually redefine their goals in politically expedient ways. Such transparency reduces the short-term macroeconomic benefits of a surprise inflation, by ensuring that economic actors can better anticipate the inflationary consequences of current policy. 
These considerations raise the question of the extent to which efforts to make central banks more independent are in conflict with the desire of governments to continue to play a role in the determination monetary policy. The Reserve Bank of New Zealand Act 1989 represents one attempt to strike a balance between these two competing priorities. The New Zealand model has been widely cited as an example of how central banks can be made more independent, without compromising political accountability. The newly independent RBNZ has achieved considerable success in its fight against inflation. New Zealand achieved the lowest rate of inflation in the OECD in the early 1990s, having had one of the highest rates for much of the 1980s. The New Zealand experience is thus worthy of examination as an attempt to put the theory of central bank independence into practice.

\section{The Reserve Bank of New Zealand Act 1989}

New Zealand experienced some of the highest rates of inflation in the OECD in the 1980 s, along with poor macroeconomic performance generally. The government passed the Reserve Bank of New Zealand Act 1989 as part of a wider program of economic reform. The Act was preceded in the mid-1980s by a change in the stance of monetary policy that 'was directed deliberately and explicitly at reducing inflation over the medium term' (Lloyd, 1992:207). It was an attempt to give a stronger institutional framework to the continued conduct of this anti-inflationary monetary policy. According to the Act, "The primary function of the Bank is to formulate and implement monetary policy directed to the economic objective of achieving and maintaining stability in the general level of prices' (RBNZ Act, 1989:9), 'while continuing to recognise the Crown's right to determine economic policy' (p.3). The Act permits the RBNZ to formulate and implement monetary policy, subject to its statutory objective and a Policy Targets Agreement (PTA) negotiated between the Governor of the RBNZ and the Minister of Finance (pp.9-10). The PTA must include a specific policy target consistent with the price stability objective, such as a specified maximum rate of annual increase in the consumer price index.

The RBNZ is not obliged to implement a government directive that the Governor considers to be inconsistent with the statutory economic objective. Where a government directive is inconsistent with the PTA, the Governor may request that a new agreement be negotiated and is absolved from meeting the existing target (p.16). However, the Act gives the government the power to override the statutory monetary policy objective by means of an Order in Council for a period of one year. The override can be renewed at the end of each year. The government can thus substitute a new economic objective, such as reducing unemployment, at any time, and renew the new objective by Order in Council every twelve months. Where use of the override provision conflicts with the current PTA, it must be abandoned and a new one negotiated (pp.11-12).

The RBNZ is thus independent largely with respect to the means of monetary policy. The broad policy goal of price stability has been enshrined in legislation, with more specific policy targets subject to negotiation with the government. The 
RBNZ's independence to pursue particular goals has been enhanced to the extent that it now has the authority to publicly defy government directives inconsistent with its statutory mandate and its Agreement with the government. In all other respects, however, specific policy objectives are assigned to it in negotiation with the government, and the statutory price stability objective is subject to government override. Use of the override provision is envisaged in the event of unexpected economic shocks that would make the achievement of the policy target or price stability unreasonable.

The Act also instituted a number of other measures designed to make the RBNZ more accountable to the government and the public. The Governor of the Bank is made personally responsible under the Act for the achievement of the PTA with the government (p.25). The Board of the RBNZ has no policy-making function under the Act. Its role is to monitor the Bank and its Governor on behalf of the government. As Lloyd notes, this means that the Board 'acts as an agent of the government' (1992:214) and ensures that responsibility for meeting policy targets is not diluted. The Minister can dismiss the Governor for failure to meet the PTA and the Board has the ability to recommend dismissal to the Minister on similar grounds (RBNZ Act, 1989:28-30). The Governor thus has very little independence from the government in relation to either policy formulation or the ability to defy the government on important issues.

The RBNZ is now significantly more accountable for its performance and enjoys a greater degree of independence in pursuing its new statutory responsibilities and those objectives determined in negotiation with the government. However, its overall goal independence is negligible and the Governor of the Bank is deliberately made vulnerable to removal from office by the government of the day for nonperformance in relation to these government-determined policy objectives. In making the Bank more accountable, the government has not made it significantly more independent. This is the product of the prevailing view that the determination of monetary policy should be subject to political direction. Lloyd agues that 'the main trade-offs [in the conduct of monetary policyl are essentially political ones, and it is appropriate that they be made clearly at the political level' (1992:210).

Reform of the RBNZ was a government initiative and reflected widespread dissatisfaction with the way monetary policy had been conducted in the past. The government, through the new Act, sought to tie itself and the Bank to an explicit pricestability objective for which the Bank could be held accountable to the government and the government would be held accountable to the electorate. The Act thus reflected 'a balance between explicit recognition that monetary policy is ultimately a government responsibility (rather than a responsibility of unelected officials), and the government's wish to constrain its own scope for monetary policy freedom in the future, and to thereby improve monetary policy credibility' (Lloyd, 1992:211). The conflict between central bank independence and accountability was thus resolved largely in favour of greater accountability, but supplemented by greater policy transparency and the enhancement of the Bank's ability to resist government demands. 


\section{The RBNZ and Inflation}

Since New Zealand embarked on an anti-inflationary monetary policy prior to the passage of the RBNZ Act 1989, the Act gave legislative backing to policy commitments that were already in place. As Pollard notes, 'New Zealand had succeeded in reducing its inflation rate from nearly 16 per cent in 1987 to six per cent before the creation of an independent central bank' (1993:30). The key to the reform was the government's willingness to adopt a policy of price stability and then precommit itself to future adherence to that policy objective by introducing greater transparency in the conduct of policy. The short-term macroeconomic benefits of inflation to the government have been reduced by ensuring that economic actors are better able to anticipate inflationary policy changes. As the Governor of the RBNZ has noted, 'politicians have actually made it difficult for themselves to abandon or emasculate the price stability objective, by making any reversions very public. They have the right under the Act to change the policy targets agreement, but they have to do it in a totally public way' (Brash, 1992:105). The reform did not rely on giving greater goal independence to the central bank, except in so far as it was given the ability to defy the government in specific instances of conflict over the achievement of predetermined policy objectives, which would require the government to publicly override the Bank. Were the government not itself genuinely committed to price stability, it is difficult to see how an anti-inflationary monetary policy could be maintained, even in the presence of a statutory commitment to price stability. The government could invoke the override provision indefinitely.

These observations support the view that the observed correlation between central bank independence and low rates of inflation may not be a causal relationship. Both may be a reflection of a broader political commitment to price stability. As Pollard has observed, central bank independence may be 'an endogenous variable in the sense that countries with a commitment to price stability may have a greater propensity for independent central banks. . In fact, a public aversion to inflation predates the establishment of many independent central banks' (1993:30). This helps to explain why superior inflation performance can be found in countries with both independent central banks (such as Germany's) and dependent ones (such as Japan). The governments most committed to the goal of price stability seem to be those of countries that have been traumatised by inflation in the past, such as Germany and New Zealand, and where the electorate is more supportive of antiinflationary monetary policies. Once inflation is correctly perceived, the benefits of inflation to the government diminish and its costs begin to rise:

... government officials and opposition leaders then find it politically rewarding to propose and enact anti-inflationary measures. A comparison with other countries that have greater monetary stability may also engender a widespread public belief (which politicians find it beneficial to respond to) that a stabilisation policy is necessary. (Bernholz, 1986:495-6) 
Cukierman has observed a tendency for central banks to acquire greater independence following the implementation of successful macroeconomic stabilisation programs. This reflects the fact that 'once they have experienced the disruptions associated with high inflation and its stabilisation, competing interest groups become more acutely aware of the benefits of avoiding those painful cycles altogether' (1992:455). The public-choice analysis of governments as habitual and chronic inflators is thus dependent on the electoral incentives to which they are subject. The New Zealand case demonstrates that such incentives need not always be proinflationary.

The success of the RBNZ Act in curbing inflation thus depends heavily on the continuation of the government's (and the electorate's) commitment to price stability. As the Governor of the RBNZ has himself noted, 'the system remains open to political reversal, and as such it is not a permanent rearrangement of the institutional structure for monetary management' (Brash, 1992:106). The government has made it more difficult for itself to abandon its commitment to price stability, but future governments could be expected to do so if it were found to be in their electoral interests.

The strength of the New Zealand reform lies more in the willingness of the current government to precommit itself to, and be held accountable for, a policy of price stability, than in the institutional design of the RBNZ Act itself. Its weakness lies in the paradox that the more apparently credible the government's commitment to price stability is, the greater incentive the government has to default on this commitment to obtain the temporary macroeconomic benefits of a surprise inflation, which in turn undermines the credibility of the original commitment (Neumann, 1991:97-8). Surprise inflation has been made more difficult by greater policy transparency. However, the potential benefits of inflation to government and other vested interests have not been eliminated, particularly once inflexible wage and price contracts come to embody lower inflationary expectations. Furthermore, the government can precommit only for the remainder of its term of office. It cannot make commitments on behalf of alternative governments that may subsequently assume power. The PTA between the Governor and the government was modified when there was a change in government in 1990 , as a result of which the time frame for the achievement of the then policy target was extended by one year (RBNZ, 1991:3). Inflationary expectations under these circumstances must have a limited time horizon. There is evidence that the duration of labour contracts in New Zealand has increased as a result of the combined effects of lower inflation and the Employment Contracts Act, but most collective employment agreements are still less than one year in duration (Fischer, 1993:25). To the extent that the new voting system in New Zealand results in unstable coalition or minority governments, the PTA between the Governor and the government of the day may not be a useful guide to future policy and have little impact on inflationary expectations. The discontinuities that elections introduce into the interaction between public and policymakers also work against the establishment of a reputational equilibrium of the type 
suggested by Barro and Gordon (1983) as a possible constraint on government behaviour.

The independence of the RBNZ is thus less of an issue than the ability of the government of the day to precommit to a policy of price stability through its relationship with the RBNZ. As Neumann argues, 'no government can provide precommitment to zero inflation by declaration or by temporary good conduct. . . Precommitment presupposes an external mechanism which effectively ties the hands of the player. . . [T]here is widespread agreement that under realistic conditions governments have no device for precommitment' (1991:98). This is because 'in order to establish a monetary standard ... the government must have the sovereign power to act as the ultimate enforcer of contractual commitments. But, this sovereign power precludes the existence of a higher authority capable of enforcing commitments about future policy choices. Consequently, any policy rule . . . can be viable only as long as it is expedient for the policy authority to follow it' (Grossman, 1991:336). The new institutional arrangements for the RBNZ and greater policy transparency do aid commitment, but there is no external mechanism to bind the government. Inflationary expectations in New Zealand need to incorporate a significant likelihood of default on current policy on the part of current or future governments.

\section{Alternative Institutional Arrangements}

A possible solution to this problem involves entrenching the price-stability objective and arrangements for the conduct of monetary policy at the constitutional level, as has been suggested by Neumann and some public choice theorists. This would entail removal of the government's ability to direct the Bank in relation to monetary policy objectives. Although New Zealand's constitution is unwritten, arrangements for the conduct of monetary policy could be given constitutional status by requiring super-majorities of parliament to overturn them. It is noteworthy that the RBNZ Act 1989 was passed with almost unanimous support in the New Zealand House of Representatives (Brash, 1992:104), thus meeting one criterion for consensual constitutional change. Unfortunately, only a simple majority would be required to overturn it. This in itself is sufficient to compromise the Bank's independence, since it will refrain from acting in a way that might cause the government to overturn the legislative basis for its independence. Statutorily independent central banks can be expected to make concessions on policy to avoid losing their independence (Goodman, 1991:335).

Like any other piece of legislation, the RBNZ Act is a reflection of current government policy commitments. The reconstitution of the RBNZ with greater statutory independence is less important to the conduct of an anti-inflationary monetary policy than the policy commitment this represents. A constitutional entrenchment of these more independent arrangements for monetary policy would greatly enhance monetary policy credibility, by reducing the prospects for a future political reversal of the present government's anti-inflationary monetary policy. 
A constitutional commitment to price stability would be incompatible with government determination of monetary policy goals. Constitutional backing would give the central bank a strong legal foundation on which to resist the policy demands of the government. The central bank could be expected to exercise near-complete discretion in setting the goals of policy, knowing itself to be well insulated from political interference. This would involve a fundamental change in the bank's relationship with the government and would effectively place monetary policy beyond political control, except in the ex ante constitutional sense.

Although the removal of politics from monetary policy would be a desirable outcome, a number of reservations are in order. Constitutional guarantees are still dependent upon strong political support if they are to be upheld and not reinterpreted into nothingness by politically-inspired higher courts. A constitutionally independent central bank would also need to be appropriately constrained to ensure that it worked in accord with a predetermined conception of where the public interest lies in the conduct of monetary policy. This might require the adoption of monetary rules to limit the discretion of the bank. A common criticism of such rules is that they lack flexibility in responding to supply and money demand shocks to the economy, and may exacerbate economic cycles. Greater central bank independence is often advocated as a way of avoiding excessive reliance on such monetary rules (Neumann, 1991:107). However, such rules may be necessary to ensure that an independent central bank is appropriately constrained and acts in the public interest. If discretionary monetary policy is dangerous in the hands of politicians, it must also be judged dangerous in the hands of a group of unelected officials.

But if monetary policy is best carried out in a constitutionally-sanctioned, independent legal framework outside the political arena, we are left with the question of whether there is any purpose in retaining responsibility for the conduct of monetary policy within the public sector. If governments are to play no post-constitutional role in the conduct of monetary policy, we need to question whether this is an appropriate area of government regulation. The issue of the appropriate degree of independence for the central bank leads naturally to an examination of alternatives to the public-sector monopoly over the supply of base money. As Selgin (1988), Dowd (1993), Greenfield and Yeager (1983) and others have demonstrated, a selfregulating monetary system based on free banking may be a viable alternative to government fiat money and the associated need for a publicly-determined monetary policy. Such a system would transcend the rules-versus-discretion debate that has plagued monetary economics in recent years and which assumes that the supply of money must be determined by a central authority.

\section{Conclusion}

The reforms to the RBNZ have yet to be fully tested, since there have not been substantial inflationary pressures in the New Zealand or world economy since 1990, when the new Act came into operation. New Zealand's continued success in combating inflation will depend as much on the government's commitment to an antiinflationary monetary policy as on the new legislative framework for the RBNZ. 
The NewZealand case demonstrates how attempts to make central banks more independent must come to grips with the problem of defining an appropriate relationship bettween the central bank and the government. This issue has so far been resolved in farour of continued government determination of the goals of monetary policy, with geater accountability and policy transparency. The government's continued commitment to price stability is thus subject to future political reversal despite the independent central bank. One solution to this problem of continued political vulnerajility is to further entrench central bank independence within a constitutionally-santioned legal framework. But such proposals raise the more fundamental question of the appropriateness of a publicly-regulated money supply, and suggest that the self-regulating, free banking alternative should be more thoroughly explored.

\section{References}

Alesina, A. \& L. Summers (1993), 'Central Bark Independence and Macroeconomic Performance', Journal of Money, Credit and Banking 25(2): 151-62.

Bade, R. \& M. Parkin (1988), Central Bank Laws and Monetary Policy, Department of Economics, University of Western Ontario, London.

Banaian, K. et d. (1983), 'Central Bank Independence: An International Comparison', in M. Toma (ed.) (1986, Central Bankers, Bureaucratic Incentives and Monetary Policy, Kluwer Academic, Dordrecht.

(forthcoming), 'On the Political Economy of Central Bank Independence', in K. Hoover \& S. Sheffrin (ecs), Monetarism and the Methodology of Economics, Edward Elgar, Aldershot.

Barro, R. \& D. Gordon (1983), 'Rules, Discretion and Reputation in a Model of Monetary Policy', Joumal of Monetary Economics 12: 101-21.

Bernholz, P. (1936), 'The Implementation and Maintenance of a Monetary Constitution', Cato Journal 6(2): 477-511.

Brash, D. (1992) 'The New Zealand Experience', in Des Moore (ed.), Can Monetary Policy be Made to Work?, Institute of Public Affairs, Melbourne.

Buckle, R. \& P. Stemp (1989), Reserve Bank Autonomy and Goverument Objectives in New Zealand: Can Tensians be Resolved? , Centre for Economic Policy Research, Australian National University, Canberra.

Cole, W. (1990), 'A More Independent Reserve Bank?', Economic Witıess, Australian Institute for Public Policy, Perth.

Crow, J. (1993), Monetary Policy and the Responsibilities and Accountability of Central Banks, Bank of Canada, Dttawa.

Cukierman, A. (1992), Central Bank Strategy, Credibility and Independesuce: Theory and Evidence, MIT Press, London. 
_ et al. (1993), 'Central Bank Independence, Growth, Investment and Real Rates', CarnegieRochester Conference Series on Public Policy 39: 95-145.

Dowd, K. (1993), Laissez-Faire Banking, Routledge, New York.

Fischer, A. (1993), 'Inflation Targeting. The New Zealand and Canadian Cases', Cato Journal 13(1): 127.

Goodman, J. (1991), 'The Politics of Central Bank Independence', Comparative Politics 23(3): 329 49.

Greenfield, R. \& L. Yeager (1983), 'A Laissez-Faire Approach to Monetary Stability', Journal of Money, Credit and Banking 15(3): 302-15.

Grilli, V. et al. (1991), 'Political and Monetary Institutions and Public Financial Policies in the Industrial Countries', Economic Policy 13 (October): 341-92.

Grossman, H. (1991), Monetary Economics', Journal of Monetary Economics 28: 323-45.

House of Commons (1993), The Role of the Bank of England, HMSO, London.

Lloyd, M. (1992), 'The New Zealand Approach to Central Bank Autonomy', Reserve Bank Bulletin (NZ) 55(3): 203-20.

McDonough, W. (1994), 'An Independent Central Bank in a Democratic Country', FRBNY Quarterly Review 19(1): 1-6.

Mayer, T. (ed.) (1990), The Political Economy of American Monetary Policy, CUP, Cambridge.

Neumann, M. (1991), 'Precommitment by Central Bank Independence', Open Economies Review 2(2): 95-112.

Pollard, P. (1993), 'Central Bank Independence and Economic Performance', Federal Reserve Bank of St Louis Review 75(4): 21-36.

Reserve Bank of New Zealand (1991), Annual Report 1991, Government Printer, Wellington.

Reserve Bank of New Zealand Act (1989), Government Printer, Wellington.

Selgin, G. (1988), The Theory of Free Banking: Money Supply under Competitive Note Issue, Rowman \& Littlefield, Totowa.

Woolley, J. (1984), Monetary Politics: The Federal Reserve and the Politics of Monetary Policy, CUP, Cambridge.

I wish to thank three anonymous referees for their comments on an earlier draft. The usual caveat applies. 